\title{
Survival in the Stone City: Tallinn in the Literature of the 1970s and 1980s
}

"There is no black soil in Mustamäe"1 (Kallas 1985: 57) ${ }^{2}$ - such is the conclusion of Uku Peterson, a character in the short story Muld (Soil) of the Estonian writer Teet Kallas, after he has searched in vain for fertile soil to grow flowers in, amidst blocks of houses in the early 1980s city-space of Tallinn. The cry of the urbanized man who has had to leave his rural background behind and come to terms with the new way of life.

The city of Tallinn went through some major changes during the 1960s and 1970s. New mass housing residential areas were built. Mustamäe was the pioneer and Lasnamäe soon followed suit. In this article, I will discuss some of the cultural aspects of those residential areas and their depiction in Soviet Estonian urban fiction of the stagnation era.

Before going any further, I would like to explain the frequent use of the word cityscape in the article. The term has already been put to good use in the field of cultural geography and urban development. In literary studies, however, it is probably not something that goes without saying. Cityscape is an artistic representation of a certain district/neighbourhood in the city, the urban equivalent of landscape. (In Estonian language, there is no strict difference between the terms - the word landscape is commonly translated as maastik which brings to mind, first of all, rural allusions.). In urban design the term refers to the configuration of built forms and interstitial space.

The term was first used in visual arts where it stands for a painting, drawing, print or photograph depicting the physical aspects

\footnotetext{
${ }^{1}$ Mustamäel pole musta mulda. This simple statement is remarkable because of the use of alliteration and wordplay - when translated literally, the place name of Mustamäe means "Black Hill". Hence the colloquialism "mäed" ("hills") to describe the suburbs of Tallinn.

${ }^{2}$ Here and in the following the translation of quoted fragments is mine. I.H.
} 
of a city or urban area. In the $17^{\text {th }}$ century Netherlands it was an independent genre. Famous painters of cityscapes include Alfred Sisley, Camille Pissarro etc.

The many virtues of the term "cityscape" have been pointed out, among others, by Edward Soja. As Soja puts it, after the term has been coined, "seeing cityscapes as cityscapes [...] opens insightful new directions that explicitly embed the interpretation of cityscapes in the wider framework of critical spatial thinking and analysis" (Soja 2006: xv). The term is closely connected to the wider spatial turn of the 20th century (ib.).

\section{Mustamäe as a cultural phenomenon}

The start of building the first Estonian mass housing district Mustamäe dates back to 1957. According to the regulation of the Central Committee of the Estonian Communist Party and the Council of Ministers "Means of developing residential housing in the ESSR", the problem of apartment shortage had to be eliminated within the next 12 years by means of producing 5.12 million square meters of living space. This policy was supported by the slogan of Nikita Khrushchev: "An apartment for every family!"

To improve the quality of housing Khrushchev emphasized the need to order the mass production of apartment buildings using standardized materials (Robinson 2009).

Extensive capacity for construction in Estonia became possible due to the establishment of the housing factory of Tallinn in 1961. The plant produced large panel elements for housing construction the Union-wide funding of which was part of the Soviet population policy (Laigu 2005: 52). ${ }^{4}$

\footnotetext{
${ }^{3}$ Abinõudest elamuehituse arendamiseks Eesti NSV-s.

${ }^{4}$ Among the goals of the Soviet population policy was the "Russification" of the Baltic areas and the rise of the new suburbs was directly associated with that. However, Mustamäe was nothing like Lasnamäe where later the number of locals probably exceeded that of the immigrants (Viires 2003: 396).
} 
HEINLOO

In its essence, Mustamäe is a modernist project. It was built to follow the free planning principle of Edouard Le Corbusier. Mustamäe was divided into mikroraions. A mikroraion was the organizational logic of the Soviet city, internally linked by pedestrian walkways that, in theory, gave access to services such as libraries, sports facilities, nurseries, health services etc, with the intent that its residents could readily and conveniently access the majority of their daily needs (Robinson 2009). As it turned out, Mustamäe soon became regarded as a bedroom community connected to the center of Tallinn via a couple of highways enabling commuters to go about their daily business outside their living quarters.

As soon as Mustamäe was established, it initiated a wide-spread public discussion which resulted in a significant amount of newspaper articles ranging from laudatory to indignant. The pros and cons, the dangers and the virtues of urban sprawl were the talk of the town, not only in architectural circles but in other cultural spheres as well. Among many prominent figures, the writers Lennart Meri and Jaan Kaplinski presented their opinions on the subject (see Meri 1981, etc).

According to sociologist Mati Heidmets, in the 1980s the public opinion turned against the new housing areas the inhabitants of which had initially felt themselves fortunate and privileged. One of the main reasons why the "experiment" failed lies in the Soviet housing policy. A pre-designed comprehensive environmental package was presented to the people that excluded the participation of users in the design process (Heidmets 1993: 83).

It is clear that because of all the hubbub around the panel housing districts they ceased to be solely an architectural peculiarity and became a cultural phenomenon. It has been pointed out in recent studies that in the 1970s and early 1980s Mustamäe was a place where a significant number of the cultural elite resided (Viires 2010: 54). Teet Kallas has written in his memoirs about more than a dozen important Estonian literary figures who, at one point or another, have all lived in Mustamäe (Kallas 2008: 324). Since many artists had their ateliers in neighbourhoods like Mustamäe, these residential areas have left their mark in visual art as well. One of the most famous paintings is "Mustamäe" (1970) by Raivo Korstnik which 
depicts the corner of a newly-built panel building with the neon-blue sky in the background Everybody knows the popular song "Mustamäe valss" (Mustamäe Waltz) which conveys the enthusiasm that went along with the rise of the new suburbs. Recent musical contributions to Mustamäe include the song "Kus on mu kodu?" (Where is my home?) by Agent $\mathrm{M}$.

Last, but not least - Mustamäe has attracted a number of film directors. A thorough overview of the depiction of panel housing districts in Estonian film is given in the works of Eva Näripea (see, for instance, Näripea 2002). Latest in the list is the internationally acclaimed movie Autumn Ball (2007), based on the novel Sügisball (Autumn Ball) by Mati Unt.

\section{From rural roots to an urbanized existence}

Of all the art forms, one of the most influenced by the changes in the cityscape of Tallinn has probably been literature. Many texts written in the 1970s and 1980s depict the panel housing district scenery. They are categorized if not as a special genre then at least as a very distinctive way of Estonian urban writing. In my work, I have been striving to find the special characteristics of some of these texts.

The "flow" of urban fiction into Estonian literature which started in the 1960s is even more remarkable when we take into consideration that Estonian literature has been traditionally centered around rural themes. In fact, it is still not clear from which point in time we can talk about the start of urbanization in Estonia.

To give an idea of the depth of the abovementioned specific genre of urban fiction in Soviet Estonia, I will mention some of the most important works from the 1970s and 1980s.

Mati Unt's novel Autumn Ball $(1978)^{5}$ is the most acclaimed piece of prose written on the subject of new residential areas during the stagnation era. The novel received good press in Estonia as well as outside, living up to the critics' as well as the readers'

\footnotetext{
${ }^{5}$ Autumn Ball is the only text referred to in the present article that has been translated into English. Autumn Ball: Scenes of City Life. Mart Aru (trans.). Tallinn: Perioodika, 1985.
} 
HEINLOO

expectations. Six different characters in the novel hardly interact with each other as the author focuses on their everyday lives in the alienating urban space of Mustamäe. Among many groundbreaking qualities of Unt's book was the treatment of subjects such as alcoholism, sexual life of the characters etc in a relatively freespirited manner which went against the grain of the strict communist moral. However, as the author effectively demonstrates, many of the problems that the characters confront, lead back to the environment that they are living in.

While Autumn Ball is regarded as an important piece of prose in Estonian literature, Teet Kallas' novel Janu (Thirst) (1983) lingers on the borderline of Estonian literary canon. Straight after its publication it received remarkably demolishing reviews. Aside from that, Janu deserves to be treated as a good example of Estonian urban prose of the 1980s which can be compared to Autumn Ball in more than a couple of ways. As an interview made with Teet Kallas in 2006 reveals, Kallas considered himself to be a good friend of the late Mati Unt. For a period in their life, both lived in the same neighbourhood, i.e. Mustamäe and, while standing by the windows of their working cabinets, could see each other from a few hundred meters' distance (Heinloo 2006).

The plot of the novel, in a nutshell: an unexpected occurrence, a disruption in water supply, forces the inhabitants of a typical panel building in a fictional town (however, with clear references to Mustamäe) to start communicating with each other. The author goes on to describe the quotidian life of urban-dwellers, mainly from the perspective of the main character Udo Munak.

Most of the characters in Janu are not the educated intellectuals that we meet in Autumn Ball. Plain, even rude language that dominates Kallas' novel is also something we do not come across often when reading Autumn Ball. However, both novels deal with the effects that a specific urban environment, a suburb like Mustamäe produces on its inhabitants. Among the negative effects are the feelings of anonymity, loneliness, inability to have healthy social relationships with the neighbours etc. 
Arvo Valton is also a noteworthy author of urban fiction from this era. Some of his short stories written in the 1970s such as Laternaad and Mustamäe armastus (Love in Mustamäe) depict life in the suburbs of Tallinn in a unique, sometimes overridingly grotesque manner.

According to recent research, Mustamäe armastus has been regarded as an early sign of postmodernism in Estonian literature (Viires 2006: 53). The characters of the short story are inhabitants of the district Mustamäe who fall in love as a result of looking each other from their apartment windows. Without any physical contact they somehow manage to conceive a child together. Laternaad is a story about the life of two street lamps in a panel housing district.

Another author that we can add to this group of writers is Jaak Jõerüüt who has contributed to the scene of "panel housing literature" with a couple of short stories and the two-part novel Raisakullid (Vultures) (1982, 1985). Raisakullid deals with many philosophical, social and moral issues but at the centre lie the aspirations of a man in search of an apartment in the panel housing district. The new residential areas are shown as prestigious neighbourhoods and indeed, as Piret Viires has written: "For many, getting a flat in Mustamäe was a chance to escape their cramped quarters in the slums or large shared apartments, and have a place of their own with all modern conveniences" (Viires 2003: 396).

The list is far from complete even if we include Astrid Reinla and her short story Muuseum (Museum) (1982) where the main character lives in an apartment in Mustamäe but decides to move out eventually.

The blossoming of urban fiction started at a time when the authorities expressed a desperate need for urban topics to be handled in literature. In fact, as the Ideological Secretary of the Estonian Communist Party Rein Ristlaan has written with obvious concern in the early 1970s: "It is beyond doubt that the future of the Estonian nation lies in urbanization. The future will be determined by the "city people", the working class which has always been the leading power in the society. [...] We do not have urban novels in our literature [...] that would demonstrate the urban life of today and the characteristics of its poetry! There seems to be no will to depict the 
HEINLOO

relations between human and artificial nature. However, that would be highly necessary. [...]" (Ristlaan 1973). ${ }^{6}$

It is hard to say if Ristlaan's article had any direct influence on the writers. Presumably not. However, the guidelines could not have been formulated more clearly. By the way, Ristlaan's essay has an allegorical title: "Juurtest ja võrsetest" (From roots to sprouts). As he explaines in the text, the roots of the Estonian writer are in the countryside whereas the sprouts should lie in the city.

Most of the Estonian writers of the 1970s were indeed not born and bred on urban asphalt. However, that does not hold true for all the writers that I have introduced here. For instance, Teet Kallas has always considered himself a native of Tallinn (Kalda 2003). Mati Unt, on the other hand, was a country boy who moved to the city in 1958. He describes the importance of the event, to some extent, in an autobiographical essay (Unt 1999), stating among other things that even in the urban environment he managed to maintain what he called "the common sense of a peasant" (terve talupojamõistus).

\section{De Bijlmer - a Dutch version of Mustamäe?}

The building of new suburbs was a result of the growth of urban population and other significant changes taking place in the postWorld War II cityscapes which was not characteristic only of this side of the Iron Curtain. Similar developments can be detected in Western Europe as well.

It is well known that during the 1960s and 1970s there were megalomaniac plans to build new cities everywhere in the world. Take for instance Brasilia, one of the most complete examples of the

\footnotetext{
${ }^{6}$ On vaieldamatu, et nagu kogu inimkonna, on ka eesti rahva tulevik linnastumises ja et järjest rohkem määrab tulevikku "linnarahvas", töölisklass, kes on olnud ja jääb ühiskonna juhtivaks, kujundavaks jõuks. [...] Linnas eluneb meie kirjanike enamik. Linnaromaani meil ometi ei ole, ei ole isegi Tallinna "pilte ja pildikesi", mis näitaksid tänast linnaelu ja selle omanäolist poeesiat! Ei ole nagu püüetki inimese ja tehislooduse vahekorra kujutamiseks. See oleks aga hädatarvilik.
} 
urban planning of utopian cities, the construction of which took just three years. The later urban development of these areas has always proven the initial idealistic thinking wrong.

For instance, in the south-eastern part of Amsterdam lies the borough Bijlmermeer (commonly known as De Bijlmer) which was designed in the 1960s as a new kind of functionalist city, a so-called residential utopia. Like Mustamäe, Bijlmer was inspired by the ideas of Le Corbusier. Many of its ideological cornerstones - apartment blocks separated by plenty of green public space; separation of living, working and recreational spaces etc - are remarkably similar to those of Mustamäe. (By the way, similar developments can be detected at the end of 1960 s in the Rahlstedt district in Hamburg, Germany.)

Through the decades Bijlmer became known as a neighbourhood with little social control and a high crime rate. Most of its inhabitants have been immigrants who could afford low-cost social housing. By now, the status of Bijlmer has changed somewhat and it has taken the form of a vibrant multicultural district. But the ambitious housing project which was meant to become Western Europe's most completely functional satellite community has been dismissed as a planning and social failure.

Because of its social problems, Bijlmer has traditionally had a bad reputation. But that is not the only reason. One of the most outstanding among the many weaknesses of Bijlmer is the puritanical landscape of its materials as the Dutch renowned architect Rem Koolhaas calls it:[...] "a spartan symphony of poured concrete, concrete block, gravel, tarred piles used as decoration, concrete tiles, galvanized metal: the Bijlmer displays more gray matter than any other place in the world" (Koolhaas 1995: 874).

However, Koolhaas finds that the Bijlmer offers boredom on a heroic scale. "In its monotony, harshness, and even brutality, it is, ironically, refreshing. [...] It even communicates [...] the secret thrill of modernization" (ib. 871).

The way Koolhaas has brought up the positive aspects of the Bijlmer neighbourhood is reminiscent of the way Mustamäe's reputation has changed in time. Eight years ago, Piret Viires wrote: "Today, forty years later, the position of Mustamäe has changed 
HEINLOO

beyond recognition. With its decaying houses - the result primarily of the poor Soviet construction quality and materials - with its shattered doors and corridors stinking of cat piss, overgrown and abandoned grassy areas, beggars and loafers wandering around, Mustamäe has become a parody of its original idea" (Viires 2003: 400). Carrying on with the same subject a few years later: "I still live in Mustamäe, I breath along with its rhythms, yet I feel that what I wrote back then isn't true anymore. Mustamäe has changed. [...] Mustamäe has been given a new life [...] it is not threatened by the dangers of ghettoisation and it is moving purposefully into the future." (Viires 2010: 52-53). ${ }^{7}$

It is worth adding that after Estonia's re-independence in 1991, examples of fiction written on the subject of mass housing areas of Tallinn have been few and far between. The theme seems to be more popular in poetry, while prose rarely offers anything worth analysing in that particular context. According to some scholars, writers have forgotten Mustamäe (Viires 2003: 400). ${ }^{8}$

\section{City and ideology}

I started the article with a quote from a character of one of Teet Kallas' short stories. Uku Peterson observes what is happening in his neighbourhood with mixed feelings. He stands confused on the street on a busy Saturday, looking at housewives cleaning their apartment windows and listening to music coming from the radios which not surprisingly includes the optimistic schlager Mustamäe valss (Kallas 1985: 55). Soil is "hidden" under the strips of grass and signs prohibit entering these areas. Peterson concludes: "A city is a city, a city has no soil, a city has no bears or wolves either, you have to go

7 Ma elan ikka Mustamäel, hingan koos tema rütmidega, kuid tunnen, et see, mida ma tookord kirjutasin, pole enam tõde. Mustamäel on midagi muutunud. [...] Mustamäe ongi uuele elule ärkamas [...], raputades end lahti getostumisohust ning liikudes sihikindlalt tulevikku.

8 The same does not seem to apply to Bijlmer, however. In 2002 a novel Vluchtwegen (Escape routes), written by the Dutch writer Michiel van Kempen was published. Vluchtwegen depicts the life of the immigrants in the Bijlmer district where van Kempen himself lived for a while. 
to the zoo to see them, only asphalt, neon and bars live in the city." (Kallas 1983: 58). ${ }^{9}$

A deeper look at the Soviet Estonian urban prose reveals that the likes of Uku Peterson are typical characters rather than exceptions, i.e. they are all in some ways concerned with how urban environment enforces itself upon nature. They try to find out if there is a possibility for nature to survive in urban surroundings.

In Teet Kallas' novel Janu, the main character Udo Munak is troubled when he sees inland seagulls in his neighbourhood: "At a distance, some inland seagulls were flying. They had discovered our district a couple of years ago, acknowlecged and conquered it. I had never come across those seagulls in the heart of the city or in the old slums. They liked it here, for some reason. What could these birds think of our district, when looking at it from up high? Maybe the grey rows of houses reminded them of a bay filled with large rocks?" (ib. 165). ${ }^{10}$

Udo bears witness to the beauty of nature seen from a distance. However, he feels trapped in his apartment with the faraway lakes and forests reminiscent of times gone by.

In the novel Autumn Ball by Mati Unt, one of the characters, a juvenile Peeter is surprised to find that sparrows are able to live in this kind of environment: "He noticed with astonishment sparrows walking on the surface of the panel blocks. They were hooked in the cracks of the wall. [...] Why did birds act this way? They probably ate the maggots they could find in the cracks. Peeter didn't believe that sparrows could eat stones.[...]" (Unt 1985: 326). ${ }^{11}$

9 Linn on linn, linnas mulda ei ole, linnas pole ka karusid ja hunte, neid näed loomaaias, linnas elavad asfalt, neoon ja baarid.

${ }^{10} \mathrm{Ja}$ eemal tiirutasid sisemaakajakad. Paari aasta eest olid nad meie linnaosa avastanud, selle omaks tunnistanud ja vallutanud. Veel kordagi polnud ma neid sisemaakajakaid kohanud südalinnas või vanades agulites. Neile meeldis millegipärast just siin. Mida võisid need linnud sealt ülalt alla vaadates meie linnaosast arvata? Võib-olla meenutas helehall majadelaam neile mingit ammukaotatud merelahte, mis oli täis pikitud suuri kandilisi kivisid?

${ }^{11}$ Hämmastusega märkas ta, et varblased kõndisid mööda majade välisseinu. Nad haakusid seinakatte mügaratesse. [...] Mis sundis linde nii tegema? 
HEINLOO

Those paragraphs help us a little closer to understanding what was going on in the psyche of urban-dwellers. All of the mentioned characters are overcome, in one way or another, by some sort of nostalgy, a longing for the "lost world".

It has been pointed out that the juxtapositiion of urban and rural culture is one of the means of stressing the distinctive urban identity. (Tüür 2002: 685). While in colloquial use the city is as a rule opposed to nature and wilderness, in reality artificial and natural environments often intertwine. Some eco-critics have suggested that the term "environment" also includes cultivated and built landscapes (Wallace, Armbruster 2001: 4), i.e. cities.

The characters of Autumn Ball, Janu and Muld discover urban nature in the most unusual places. The opposition of city vs. nature / city vs. countryside has, in this case, an additional ideological context. We have to keep in mind that because of the censorship and the difficult working conditions of the writers of the stagnation era, a secret message was often conveyed to the reader who was used to reading between the lines. We can assume that the way the topic was handled in literature was part of a kind of a protest against the demands of the official ideology regarding Soviet urban planning which, in turn, was part of the Soviet progress myth (Sooväli 2008). "Writing about nature (outside as well as inside the city - I. H.) became another concealed possibility to express one's quest for freedom in the framework of the official culture and literature" (Maran, Tüür 2001).

During the Soviet era, nature protection (loodushoid) had a meaning attached to it that goes deeper than the word itself implies. Preserving nature (natural resources) was a way of preserving culture. For instance, Estonia was the first republic in the USSR to create national parks (for more information on that, see Smurr 2008).

The environmental/ecological aspects of urban fiction from the 1970s and 1980s have been emphasized by other scholars as well. For instance, Maie Kalda has pointed out that Teet Kallas brings a shade of green into the grey scenery of Tallinn which can be directly

Küllap nad sõid paneelipragudest vastseid. Peeter ei uskunud, et varblased söövad kive. [...] 
associated with the international green movement that was popular at the time. Kalda refers to the green (sic!) cover picture of Kallas' short story collection Ö̈ neljandas mikrorajoonis (Night in the fourth microrayon) (which includes the abovementioned piece Muld) depicting a huge apple-tree growing out of a multi-storey building in Mustamäe. According to Maie Kalda, the general tendency in the prose and poetry of the seventies was to regard the urban dweller as somebody who brutally desecrates nature (Kalda 2003: 601).

Another bundle of topics that cannot be overlooked while analyzing the Soviet Estonian urban fiction and which I will only briefly touch upon, is the distinction between private and public space. Panel housing districts as a living space stressed the importance of collective rather than individual identity. In other words - officially, private space did not exist. Technically, all citizens had legitimate claims to all spaces because they were considered public space. What happened was that the "unofficial" private space became the real centre of social life (Robinson 2009). Let me give a couple of examples on how this duality was presented in literature.

Among the many urban-themed short stories of Jaak Jõerüüt is a significant, though less-known piece called Räägivad ja vaikivad (They talk and remain silent). In this short story a couple moves into a brand new apartment in a multi-storey building which they describe, at first, as "untouched from lives, sterile" (Jõerüüt 1980: 35). It soon becomes a place of get-together for a circle of friends, a place to hide themselves from the outside world. Because of the fact that the outside world does not really belong to anybody, the urbandwellers often feel complete indifference towards it.

It has been written in a recent study of Soviet city: "But people needed real places. They needed places that they themselves would imbue with meaning and over which they could exercise some control, places where they could breathe more easily and relate to one another. The foremost place of this sort was the home, especially its kitchen. Only there did people feel most comfortable" (Argenbright 1999: 7). And indeed, this is exactly the conclusion of Udo Munak in Teet Kallas' novel Janu when he remembers the way his forefathers used to sit in the kitchen, stare into the twilight outside and have a nice, oldfashioned conversation (Kallas 1983: 25). 
HEINLOO

\section{Conclusion}

There are multiple ways to approach the many-faced cultural phenomena of panel housing districts which, despite being part of the global urbanization process, gains an additional dimension when placed in the Soviet Estonian context. Nevertheless, it is possible to compare Mustamäe, from an ideological and planological point of view, with, for instance, the Bijlmer district in Amsterdam, Holland.

Back in the 1970s and 1980s, literature was a major output for sociocritical analysis of architectural developments. The switch from rural to urban mentality did not happen painlessly - in the urban fiction of the stagnation era we see how rural past is often nostalgically looked back at.

The Soviet city was an ideologized space. As many scholars have pointed out, by favouring public over private space and collective over individual identity, the urban planners did not succeed in making the new suburbs a pleasant environment for citizens. This is also one of the issues that the fiction written in the 1970s and 1980s is dealing with.

In the last decades, there has been a significant decrease in the popularity of the theme of mass housing residential areas in literature. Suburbs like Mustamäe no more attract the attention that they were granted so profusely during the era of stagnation.

\section{References}

Argenbright, R. 1999. Remaking Moscow: New places, new selves. Geographical Review 89(1), 1-22.

Heidmets, M. 1993. Mass housing areas and their young inhabitants:

Situation in former Soviet territories. - Ekberg, K., Mjaavatn, P.E. (eds.)

Children at risk: selected papers. Trondheim: The Norwegian centre for

Child Research, 111-114.

Heinloo, I. 2006. Tallinna paneellinnaosade temaatika Eesti kirjanduses. Bachelor's thesis.

Kalda, M. 2003. Teet Kallase Tallinn. - Looming 4, 594-601.

Kallas, T. 1983. Janu. Tallinn: Eesti Raamat.

Kallas, T. 1985. Ö̈̈ neljandas mikrorajoonis. Tallinn: Eesti Raamat. 
Kallas, T. 2008. Kakskümmend seitse hetke Mati Undiga. - Kesküla, K. (ed.) Undi-jutud. Mälestusi Mati Undist. Tartu: Hermes, 306 - 347.

Koolhaas, R., Mau, B. 1995. Small, Medium, Large, Extra-Large Office for Metropolitan Architecture. Rotterdam: 010 Publishers.

Laigu, T. 2005. Estonian Megastructure Reuse. - Briseno, A. (ed.) 30609008: Autonomous Urbanism. Princeton Architectural Press, 5153.

Maran, T., Tüür, K. 2001. On Estonian nature writing. - Estonian Literary Magazine 13, 4-10.

http://elm.estinst.ee/issue/13/estonian-nature-writing/

Meri, L. 1981. Aiaäärne majadetagune. - Looming 2, 261-269.

Näripea, E. 2002. Kaadreid modernistlikust ideaallinnast: "Viini Postmark" ja Mustamäe. - Sarapik, K., Kalda, M., Veidemann, V. (ed.-s) Kohandumise märgid. Collegium litterarum 16. Tallinn: Underi ja Tuglase Kirjanduskeskus, 142-160.

Reinla, A. 1982. Inimestega. Tallinn: Eesti Raamat.

Ristlaan, R. 1973. Juurtest ja võrsetest. - Looming 5, 867-868.

Robinson, J. 2009. The Post-Soviet City: Identity and Community Development. - City Futures in a Globalising World (an international conference on globalism and urban change).

http://www.cityfutures2009.com/PDF/89_Robinson_Jill.pdf

Smurr, R.W. 2008. Lahemaa: the paradox of the USSR's first national park. - Nationalities Papers 36, 399-423.

Soja, E.W. 2006. Foreword. - Lindner, C. (ed.) Urban Space and Cityscapes: Perspectives from Modern and Contemporary Culture. Routledge, xvi-xviii.

Sooväli, H. 2008. Maastiku kirurgia. - Vikerkaar 7, 8, 130-137.

Tüür, K. 2002. Aiad ja jõed: linnaloodusest Tõnu Õnnepalu romaanides. Keel ja Kirjandus 10, 681-691.

Unt, M. 1985. Sügisball. - Valitud teosed 2, 306- 430.

Unt, M. 1999. Maapoisi tee linnakirjandusse. - Looming 8, 1246-1252.

Van Kempen, M. 2006. Vluchtwegen. Breda: De Geus.

Viires, P. 2003. Mustamäe Metamorphoses. - Sarapik, V., Tüür, K. (ed.-s) Koht ja paik. Place and Location. Tallinn: Eesti Kunstiakadeemia, 395403.

Viires, P. 2006. Postmodernism Eesti kirjanduskultuuris. Dissertationes litterarum et contemplationis comparativae Universitas Tartuensis 5. Tartu: Tartu Ülikooli Kirjastus.

Viires, P. 2010. Mustamäe - kolmkümmend aastat hiljem. - Sarapik, V., Viires, P. (eds.) Etüüde nü̈̈diskultuurist 2. Sügisball. Tallinn-Tartu: Eesti Kirjandusmuuseum. 
HEINLOO

Wallace, K., Armbruster, K. 2001. Introduction. Why go beyond nature writing and where to? - Armbruster, K., Wallace, K. (eds.) Beyond Nature Writing: Expanding the Boundaries of Ecocriticism. Charlottesville, London: University Press of Virginia, $1-25$. 